\section{Response to: 'Correspondence on 'Lupus or not? SLE Risk Probability Index (SLERPI): a simple, clinician-friendly machine learning-based model to assist the diagnosis of systemic lupus erythematosus' by Batu et al}

We would like to thank Batu et $\mathrm{al}^{1}$ for the interest in our work and for evaluating the performance of SLE Risk Probability Index (SLERPI) ${ }^{2}$ in paediatric SLE patients. In their analysis using the simple scoring version of the index as a binary outcome, the sensitivity and specificity was $90.0 \%$ and $81.2 \%$, respectively. ${ }^{1}$ Applying a more stringent cut-off of $>8$ resulted in a sensitivity of $81.2 \%$ and a specificity of $89.4 \%$. Notably, the area under the receiver operating characteristic curve of the scoring version of SLERPI was 0.94 (95\% CI 0.919 to 0.968 ), suggesting a good discriminating capacity. ${ }^{1}$

To put these results into context, one should consider the fact that the SLERPI was developed based on features derived from exclusively adult patients, ${ }^{2}$ the index performs optimally as a continuous probabilistic (rather than binary) model (https://www.rheumatologyuoc.gr/en/slerpi) to produce diagnostic certainty levels and finally, features should be counted only if there is no better explanation according to the attribution rule of the European League Against Rheumatism (EULAR)/American College of Rheumatology (ACR) 2019 classification criteria. ${ }^{3-5}$ In this regard, previous studies have indicated a tendency for lower overall performance of the SLE classification criteria, especially the ACR 1997 and EULAR/ACR 2019, in childhood-onset/juvenile patients with early disease, ${ }^{6-8}$ although there is scantiness of direct adult-paediatric comparative analyses. Interestingly, and in line with the suggestion by Batu et al ${ }^{1}$ for using a higher SLERPI cut-off point $(>8)$, increasing the classification threshold of the EULAR/ACR 2019 criteria resulted in enhanced specificity to detect paediatric cases of SLE versus mimicking disorders. $^{79}$

On another point, Batu et al ${ }^{1}$ reported haemolytic uremic syndrome (HUS) and mixed connective tissue disease (MCTD) as the two diseases most frequently misclassified as SLE by the SLERPI. Although we acknowledge that neither disorder was included in the SLERPI derivation or validation datasets, HUS is rarely encountered during adult life. MCTD can indeed be challenging to differentiate from lupus, which may contribute to reduced specificity of the existing SLE classification criteria. ${ }^{9}{ }^{10}$ Intriguingly, a significant proportion of patients initially diagnosed as MCTD may evolve into another defined connective tissue disease including $\mathrm{SLE}^{11}$; therefore, it would be tempting to evaluate SLERPI as a prognostic index in such cases.

To this end, we welcome the initiative of Batu et al to evaluate SLERPI in paediatric cases, as well as any future efforts to further validate and calibrate the utility of this tool in different clinical settings and populations.

\section{Christina Adamichou $\odot{ }^{1}$ George Bertsias ${ }^{2,3}$ \\ ${ }^{1}$ Rheumatology, University of Crete School of Medicine, Heraklion, Greece ${ }^{2}$ Rheumatology, University of Crete School of Medicine, Iraklio, Crete, Greece ${ }^{3}$ Laboratory of Autoimmunity-Inflammation, Institute of Molecular Biology and Biotechnology, Heraklion, Crete, Greece}

Correspondence to Dr George Bertsias, Rheumatology, University of Crete School of Medicine, Iraklio, Crete 71008, Greece; gbertsias@uoc.gr
Handling editor Josef S Smolen

Collaborators GB and CA drafted the text.

Contributors $C A$ and $G B$ drafted the response letter.

Funding The authors have not declared a specific grant for this research from any funding agency in the public, commercial or not-for-profit sectors.

Competing interests None declared.

Patient and public involvement Patients and/or the public were not involved in the design, conduct, reporting or dissemination plans of this research.

Patient consent for publication Not required.

Provenance and peer review Not commissioned; externally peer reviewed. (C) Author(s) (or their employer(s)) 2021. No commercial re-use. See rights and permissions. Published by BMJ.

\section{Check for updates}

To cite Adamichou C, Bertsias G. Ann Rheum Dis Epub ahead of print: [please include Day Month Year]. doi:10.1136/annrheumdis-2021-220262

Received 17 March 2021

Accepted 18 March 2021

\section{Linked}

- http://dx.doi.org/10.1136/annrheumdis-2021-220246

Ann Rheum Dis 2021;0:1. doi:10.1136/annrheumdis-2021-220262

ORCID iD

Christina Adamichou http://orcid.org/0000-0001-7374-7795

\section{REFERENCES}

1 Batu ED, Akca UK, Basaran O. Correspondence on "Lupus or not? SLE Risk Probability Index (SLERPI): a simple, clinician-friendly machine learning-based model to assist the diagnosis of systemic lupus erythematosus". Ann Rheum Dis 2021. doi:10.1136/ annrheumdis-2021-220246

2 Adamichou C, Genitsaridi I, Nikolopoulos D, et al. Lupus or not? SLE risk probability index (SLERPI): a simple, clinician-friendly machine learning-based model to assist the diagnosis of systemic lupus erythematosus. Ann Rheum Dis 2021. doi:10.1136/ annrheumdis-2020-219069. [Epub ahead of print: 10 Feb 2021].

3 Aringer M, Brinks R, Dörner T, et al. European League Against Rheumatism (EULAR)/ American College of Rheumatology (ACR) SLE classification criteria item performance. Ann Rheum Dis 2021. doi:10.1136/annrheumdis-2020-219373. [Epub ahead of print: 10 Feb 2021].

4 Aringer M, Costenbader K, Daikh D, et al. 2019 European League against Rheumatism/American College of rheumatology classification criteria for systemic lupus erythematosus. Arthritis Rheumatol 2019;71:1400-12.

5 Aringer M, Costenbader K, Daikh D, et al. 2019 European League against Rheumatism/ American College of rheumatology classification criteria for systemic lupus erythematosus. Ann Rheum Dis 2019;78:1151-9.

6 Aljaberi N, Nguyen K, Strahle C, et al. The performance of the new 2019-EULAR/ACR classification criteria for systemic lupus erythematosus in children and young adults. Arthritis Care Res 2020. doi:10.1002/acr.24430. [Epub ahead of print: 25 Aug 2020].

7 Fonseca AR, Rodrigues MCF, Sztajnbok F, et al. Does leukopenia influence performance of the new European League against Rheumatism/American College of rheumatology classification criteria in an African-Descendent population with childhood-onset systemic lupus erythematosus? Comment on the article by Aringer et al. Arthritis Rheumatol 2020;72:694-5.

8 Levinsky Y, Broide M, Kagan S, et al. Performance of 2019 EULAR/ACR classification criteria for systemic lupus erythematosus in a pediatric population - a multicenter study. Rheumatology 2021.

9 Batu ED, Kaya Akca U, Pac KIsaarslan A, et al. The performances of the ACR 1997, SLICC 2012, and EULAR/ACR 2019 classification criteria in pediatric systemic lupus erythematosus. J Rheumatol 2020:jrheum.200871.

10 Mesa A, Fernandez M, Wu W, et al. Can SLE classification rules be effectively applied to diagnose unclear SLE cases? Lupus 2017;26:150-62.

11 Montolio-Chiva L, Narváez J, Pascual M. AB0593 does really exist mixed connective tissue disease? Annals of the Rheumatic Diseases 2020;79:1593. 